Iranian Evolutionary

(C) 2019, University of Hormozgan Publication

and Educational Psychology Journal

\title{
Study of the Psychological Problems in 7-11 Year-old Children of Divorce Based on the Attitudes of Iranian Teachers and Mothers
}

\author{
Zohre Esmaeilian-Ardesntani ${ }^{1}$, Mehrdad Kalantari ${ }^{2 *}$, Hooshng Talebi ${ }^{3}$, Mohammad Reza Abedi ${ }^{4}$ \\ 1. Ph.D student of Psychology, University of Isfahan, Isfahan, Iran \\ 2. Professor of Psychology, Department of Psychology, University of Isfahan, Isfahan, Iran (corresponding author) \\ 3. Associate Professor, Department of Statistics, University of Isfahan, Isfahan, Iran \\ 4. Professor, Department of Counseling, University of Isfahan, Isfahan, Iran
}

\begin{abstract}
The main objective of this study is to identify the psychological problems of 7-11 year-old children of divorce based on the lived experience of teachers and mothers. The research method used was one of a descriptive survey with the statistical population comprising elementary school male and female children aged 7-11. From this number, 280 comprised the sample selected from all the boys' and girls' schools in Esfahan using a multi-stage cluster sampling. The data collection instrument was the Achenbach questionnaire (Mother and Teacher inventory). The data were analyzed using Chi-square test where upon the results indicated that based on the mothers' reports, the commonest problems were complaints about physical pain (6.8\%), withdrawal, depression, aggressive behavior (6.4\%), and physical problems $(6 \%)$. Furthermore, based on the teachers' reports, the commonest problems were anxiety or depression, physical and behavioral problems (6.4\%), aggressive behavior, emotional problems (6\%), and social problems $(5.7 \%)$.
\end{abstract}

Keywords: Divorce, child, psychological problems, attitude, teacher, parent

\section{Introduction}

Family, the earliest social unit that the child copes with plays a major and constructive role in the shaping of personality. Thus, an undermined family foundation has devastating consequences for the child. Divorce is the leading cause for disintegration of family, the most fundamental part of the society(George J Cohen, Weitzman, Child, \& Health, 2016; S. Cohen, Klein, \& O'Leary, 2007). Most of the research conducted on children of divorce started in the 1970's (Kramer \& Smith, 1998). Joan B Kelly and Wallerstein (1977), the first pioneers in the field, referred to divorce as a potential cause for the developmental problems of children. Numerous studies have indicated that divorce and separation are the only recognized childhood stresses that can have adverse consequences for children(Noller, Feeney, Sheehan, Darlington, \& Rogers, 2008).

The studies referring to the problems of children of divorce are: anxiety(Begmuaras, 2010; Hoyt, Cowen, Pedro-Carroll, \& Alpert-Gillis, 1990; LeGrand, 1990; Noller et al., 2008; Steinberg \& Silverberg, 1987), depression(Liu et al., 1999; Rodgers \& Rose, 2002), poor mental health(Gardner, 1985), self-esteem(Amato, 1994; George J. Cohen, 2002; Joan B. Kelly, 2000; Mota \& Matos, 2009), neural tension(Younesi, Moein, \& Shamshirinia, 2010), anger and aggressiveness(Emery, 2011; Rodgers \& Rose, 2002), guilt feelings(Rodgers \& Rose, 2002; Szwedo, Hessel, \& Allen, 2017), feelings of insecurity(Grour, Thomas, \& Shoffner, 1992), problems with adjustment(Amato, 1994; Joan B. Kelly, 2000), further internalized and externalized behaviors(George J. Cohen, 2002), unsafe attachment(Fridman-Teutsch \& AttarSchwartz, 2018; Friesen, Woodward, Horwood, \& Fergusson, 2013; Mota \& Matos, 2009; Ottaway, 2010; Samuels, Stockdale, \& Crase, 1994), psychological problems(Pirak, Negarandeh, \& Khakbazan, 2019), physical problems(Amato, 2001; Brewer, 2006), malnutrition, loss of

To cite this paper: Esmaeilian-Ardesntani, Z.,Kalantari, M., Talebi, H. \& Abedi, M. (2019). Study of the Psychological Problems in 7-11 Year-old Children of Divorce Based on the Attitudes of Iranian Teachers and Mothers. Iranian Evolutionary and Educational Psychology Journal, 1, 2, 88-95. 
appetite, hyperphagia, and insomnia(Younesi et al., 2010), negative self-image and fatigue(Teyber, 2001), loneliness and feeling different from other children(Aziz et al., 2018), declined academic performance(Amato, 1994; Kramer \& Smith, 1998), social problems, poor social development, social conflicts with peers and family members(Amato \& DeBoer, 2001; $\underline{\mathrm{E}}$ Mavis Hetherington, 1999; Richardson \& McCabe, 2001; Størksen, Røysamb, Holmen, \& Tambs, 2006), problems with responsibility(Younesi et al., 2010), declined activity and performance, withdrawal, daydreaming(Weyer \& Sandler, 1998), personality disorder(Grour et al., 1992).

To explain the cause of problems in children of divorce, it can be claimed that absence of either parent in the family can undermine the balance, stability, and security of children with adverse consequences for their natural growth, adjustment, and mental health(E. Mavis Hetherington \& Stanley-Hagan, 1995; Marquardt, 2011). Such children are not usually prepared enough to hear about the separation of their parents. Besides, they do not realize what divorce is or why it ever occurs. Consequently, they get worried with the result of further psychological problems for them(Walker, 2003).

Furthermore, some children believe that parents are to blame for the divorce. For this reason, guilt feeling is common among them(Wolchik, Tein, Sandler, \& Doyle, 2002). Also when divorce occurs, the conflicts between the parents continue over child sponsorship, visitation, discipline, and adjustment to divorce(Buchanan \& Heiges, 2001).

Following divorce, a common feeling that children may experience is that of getting stuck in between the parents, for each parent seeks to justify themselves, turning to their children for further support(Afifi, 2003; Golish, 2003). The dichotomy of the educational system is a major problem of children bringing them into conflicts. Furthermore, with divorce, changes occur in the life style of most children, restricting their access to sources of support(Golombok, 2004).With parental remarriage, great changes occur in the lives of their children. Researchers have indicated that children of step-families have more behavioral problems and more adjustment difficulties, and that compared to single-parent families, step-children experience further unpleasant consequences(E Mavis Hetherington, Bridges, \& Insabella, 1998; Teachman, Paasch, \& Carver, 1996). The above studies and a host of others are reminiscent of a multitude of problems for children of divorce. However, not all the problems have been addressed in an exhaustive study to enable access to a particular paradigm of psychological problems of children. Moreover, naturally each problem calls for their unique solutions, with none being applicable for prevention or treatment without considering other solutions. Therefore, in view of the growing statistics of divorce and the adverse effects on the mental health of children, the high recurrence rate of psychological problems in children of divorce, and the effect of these problems on the family and society, the psychological problems of these children have received special attention and the urgency of timely intervention to minimize and destabilize the premature intensity of the symptoms is inevitable. It seems that an exhaustive study to diagnose the problems can help parents and specialists to prevent and solve the children's problems. In this study, attempts have been made to identify and prioritize the problems. 


\section{Material and Methods}

In view of the aim of identifying the psychological problems in 7-11 year-old children of divorce, the research method used was one of a descriptive survey. The statistical population comprised elementary school children, boys and girls aged 7-11, studying at six areas of the Education Department, Esfahan. The requirements for child selection were the mother's divorce and the child's living with the mother. The sample size was 280 selected on a multi-stage cluster basis from all the boys' and girls' schools in Esfahan.

Achenbach Questionnaire: This test comprises two Child Behavior Checklists (CBCL) completed by mother or the child's sponsor and a Teacher Report Form (TRF) completed by the teacher used to verify and prioritize the problems with children of divorce. The dimensions covered by these tools include anxiety/depression, withdrawal/depression, physical complaints, social complaints, thinking problems, focusing problems, law-breaking behavior, aggressive behavior, other problems, affective problems, anxiety-related problems, physical problems, Attention Deficit Hyperactivity Disorder (ADHD), problems of counteractive behavior, and behavioral problems. The number of question items in this inventory was 113 . The respondents were to grade the child's status over the past six months with 0,1 , and 2 . The internal consistency coefficient of the scales ranged from 0.63 to 0.95 . The validity of the test using test-retest method and Pearson's correlation coefficient for all the subscales ranged from 0.32 to 0.67 and was significant at $\mathrm{P}<0.05$ level. To investigate the criterion-related validity, the Parental Account of Symptoms inventory was used for this purpose. Furthermore, in Rescorla et al. (2007), the internal consistency coefficient ranged from 0.63 to 0.95 and the temporal stability of the scales using test-retest with a 5-8 week interval ranged from 0.32 to 0.67 . The research data were analyzed using a Chi-Square test depending on the aim of the study.

\section{Results}

Table 1 presents the frequency and frequency proportion of the psychological problems of children of divorce based on mothers' reports. As can be seen from Table 1, based on mothers' reports, the recurrence of psychological problems in children of divorce in descending order of frequency proportion is as follows:

1. Physical complaints: 6.8 ,

2. Withdrawal/depression and aggressive behavior, each: 6.04,

3. Physical problems: 6,

4. Social problems, other problems, and behavioral problems, each: 5.7,

5. Thinking problems, anxiety problems, ADHD, each: 5.3,

6. Law-breaking behavior: 4.6,

7. Anxiety/depression: 4.3,

8. Focusing and affective problems: 3.9 , and

9. Counteractive problems: 3.5 
Table 1. Frequency and Frequency proportion of the psychological problems of children of divorce based on mothers' reports

\begin{tabular}{|c|c|c|c|c|c|c|c|c|}
\hline \multirow[t]{3}{*}{ Item } & \multirow[t]{3}{*}{ Behavioral Disorders } & \multicolumn{6}{|c|}{ Mother's Report } & \multirow[t]{3}{*}{ Chi-Square } \\
\hline & & \multicolumn{2}{|c|}{ Clinical Range } & \multicolumn{2}{|c|}{ Borderline Range } & \multicolumn{2}{|c|}{ Normal } & \\
\hline & & $\mathrm{F}$ & $\mathrm{F} \%$ & $\mathrm{~F}$ & F\% & $\mathrm{F}$ & F\% & \\
\hline 01 & Anxiety/ Depression & 12 & 4.3 & 10 & 3.5 & 259 & 92.2 & 437.77 \\
\hline 02 & Withdrawal/ Depression & 17 & 6.04 & 11 & 3.91 & 253 & 90 & 406.75 \\
\hline 03 & Physical/ Complaints & 19 & 6.8 & 5 & 1.8 & 257 & 91.4 & 428.27 \\
\hline 04 & Social Complaints & 16 & 5.7 & 17 & 6.04 & 248 & 88.2 & 381.44 \\
\hline 05 & Thinking Problems & 15 & 5.3 & 4 & 1.4 & 262 & 93.2 & 454.43 \\
\hline 06 & Focusing Problems & 11 & 3.9 & 14 & 4.98 & 256 & 91.1 & 422.06 \\
\hline 07 & Law-breaking Behavior & 13 & 4.6 & 10 & 3.55 & 258 & 91.8 & 432.52 \\
\hline 08 & Aggressive Behavior & 17 & 6.04 & 6 & 2.1 & 258 & 91.8 & 433.12 \\
\hline 09 & Other Problems & 16 & 5.7 & 11 & 3.9 & 254 & 90.4 & 411.81 \\
\hline 10 & Affective Problems & 11 & 3.9 & 14 & 4.98 & 256 & 91.1 & 422.06 \\
\hline 11 & Anxiety Problems & 15 & 5.3 & 14 & 4.98 & 252 & 89.7 & 401.47 \\
\hline 12 & Physical Problems & 17 & 6 & 5 & 1.8 & 259 & 92.2 & 438.52 \\
\hline 13 & ADHD & 15 & 5.3 & 18 & 6.4 & 248 & 88.25 & 381.49 \\
\hline 14 & Counteractive Problems & 10 & 3.5 & 7 & 2.5 & 264 & 93.9 & 464.68 \\
\hline 15 & Behavioral Problems & 16 & 5.7 & 7 & 2.5 & 258 & 91.8 & 432.9 \\
\hline
\end{tabular}

Table 2 presents the frequency and frequency proportion of the psychological problems in children of divorce based on the teachers' reports.

Table 2. Frequency and frequency proportion of the psychological problems of children of divorce based on the teachers' reports

\begin{tabular}{|c|c|c|c|c|c|c|c|c|}
\hline \multirow[t]{3}{*}{ Item } & \multirow[t]{3}{*}{ Behavioral Disorders } & \multicolumn{6}{|c|}{ Teacher's Report } & \multirow[t]{3}{*}{ Chi-Square } \\
\hline & & \multicolumn{2}{|c|}{ Clinical Range } & \multicolumn{2}{|c|}{ Borderline Range } & \multicolumn{2}{|c|}{ Normal } & \\
\hline & & F & F\% & $\mathrm{F}$ & F\% & $\mathrm{F}$ & F\% & \\
\hline 01 & Anxiety/ Depression & 18 & 6.4 & 12 & 4.3 & 251 & 89.3 & 396.6 \\
\hline 02 & Withdrawal/ Depression & 10 & 3.5 & 26 & 9.2 & 245 & 87.2 & 368.12 \\
\hline 03 & Physical/ Complaints & 15 & 5.3 & 11 & 3.9 & 255 & 90.7 & 416.91 \\
\hline 04 & Social Complaints & 16 & 5.7 & 10 & 3.6 & 255 & 90.7 & 417.02 \\
\hline 05 & Thinking Problems & 14 & 5 & 12 & 4.3 & 255 & 90.7 & 416.85 \\
\hline 06 & Focusing Problems & 12 & 4.3 & 19 & 6.8 & 250 & 89 & 391.65 \\
\hline 07 & Law-breaking Behavior & 15 & 5.3 & 7 & 2.5 & 259 & 92.2 & 438.09 \\
\hline 08 & Aggressive Behavior & 17 & 6 & 9 & 3.2 & 255 & 90.7 & 405.41 \\
\hline 09 & Other Problems & 14 & 5 & 6 & 2.1 & 261 & 92.9 & 448.75 \\
\hline 10 & Affective Problems & 17 & 6 & 6 & 2.1 & 258 & 91.8 & 433.12 \\
\hline 11 & Anxiety Problems & 14 & 5 & 10 & 3.5 & 257 & 91.4 & 427.31 \\
\hline 12 & Physical Problems & 18 & 6 & 0 & 0 & 263 & 93.5 & 213.61 \\
\hline 13 & ADHD & 11 & 3.9 & 17 & 6 & 253 & 90 & 406.75 \\
\hline 14 & Counteractive Problems & 10 & 3.5 & 29 & 10.3 & 242 & 86.1 & 354.28 \\
\hline 15 & Behavioral Problems & 18 & 6.4 & 9 & 3.2 & 254 & 90.4 & 412.11 \\
\hline
\end{tabular}


As can be seen from Table 2, based on the teachers' report, the recurrence of psychological problems in children of divorce in descending order of frequency proportion is as follows:

1. Anxiety/depression, physical problems, and behavioral problems, each: 6.4 ,

2. Aggressive behavior and affective problems, each: 6,

3. Social complaints: 5.7 ,

4. Physical problems and law-breaking behavior, each: 5.3,

5. Other problems, anxiety problems, and thinking problems, each: 5,

6. Focusing problems: 4.3,

7. ADHD: 3.9 , and

8. Withdrawal/depression and problems of counteractive behavior, each: 3.5

\section{Discussion}

The findings indicating that anxiety is a major index of the behavioral problems with children of divorce. Furthermore, the findings of Liu et al. (1999), Rodgers and Rose (2002) emphasizing the depression problem as well as the findings of Rodgers and Rose (2002) and Emery (2011), revealing anger and aggressiveness in this group, the findings of Amato (2001) and (Brewer, 2006) emphasizing their physical problems, the findings of Amato and DeBoer (2001), Richardson and McCabe (2001) and Størksen et al. (2006) revealing poor social relations, poor social growth, and social conflicts with peers and family members in this group are consistent.

To explain the results thus obtained, one can claim that divorce and separation are among the recognized childhood stresses with unpleasant adverse effects on children(Noller et al., 2008). The divorce process usually involves numerous stressful events for children such that most children of divorce experience: their economy declines, they are abandoned by either one or both parents, or have fear of being abandoned, for both parents are busy with their own problems and have little time to attend to their children's needs, and that the children's contact with familiar sources of mental and social sources of support diminishes.

Moreover, with divorce, the life styles of most children change. As a result, the divorce experience ensues negative mental, social, and physical consequences for most children(Amato, 1999; Brewer, 2006; Carlson \& Corcoran, 2001; Frieman, 1994). Currently, there seems to be need for a professional and provisional outlook on the problems of children of divorce in order that parents, the mothers in particular, of such children as well as counselors and specialists can be informed of the major problems of the children, and seek to both prevent their problems and develop an efficient therapeutic approach to their problems. In view of the results of this study, it is recommended that focus on such major indices as physical complaint, withdrawal and depression, aggressive behavior, anxiety, physical and social problems in children of divorce, the above items be given priority by the therapist to help the children better adjust to the new living conditions and cope with the pains.

\section{References}

Afifi, T. D. (2003). 'Feeling Caught' in Stepfamilies: Managing Boundary Turbulence through Appropriate Communication Privacy Rules. Journal of Social and Personal Relationships, 20(6), 729-755. doi:10.1177/0265407503206002 
Amato, P. R. (1994). Life-Span Adjustment of Children to Their Parents' Divorce. The Future of Children, 4(1), 143-164. doi:10.2307/1602482

Amato, P. R. (1999). Children of divorced parents as young adults: Mahwah, N.J: Erlbaum.

Amato, P. R. (2001). Children of divorce in the 1990s: an update of the Amato and Keith (1991) meta-analysis. Journal of family psychology, 15(3), 355.

Amato, P. R., \& DeBoer, D. D. (2001). The Transmission of Marital Instability Across Generations: Relationship Skills or Commitment to Marriage? Journal of Marriage and Family, 63(4), 1038-1051. doi:10.1111/j.1741-3737.2001.01038.x

Aziz, R. A., Agustina, S., Yahaya, H., Mokhtar, W. N. H. W., Hashim, D. M., Shaifuddin, N., \& Wahid, L. A. (2018). The Impact of Using Children\&\#8217;s Literature for Bibliotherapy Purposes on Children Experiencing Divorce. Advanced Science Letters, 24(1), 378-380. doi:10.1166/asl.2018.12014

Begmuaras, E. (2010). The Effects of sepraration, Divorce and conflict on Turkish children. The Chicago.

Brewer, R. W. (2006). Parental Relationships and Emotional Distress and Well-Being Among College Women. University of Cincinnati. Retrieved from http://rave.ohiolink.edu/etdc/view?acc_num=ucin1163542389

Buchanan, C. M., \& Heiges, K. L. (2001). 13 When Conflict Continues after the Marriage Ends. Interparental conflict and child development: Theory, research and applications, 337.

Carlson, M. J., \& Corcoran, M. E. (2001). Family Structure and Children's Behavioral and Cognitive Outcomes. Journal of Marriage and Family, 63(3), 779-792. doi:10.1111/j.17413737.2001.00779.x

Cohen, G. J. (2002). Helping Children and Families Deal With Divorce and Separation. Pediatrics, 110(5), 1019-1023.

Cohen, G. J., Weitzman, C. C., Child, C. o. P. A. o., \& Health, F. (2016). Helping children and families deal with divorce and separation. Pediatrics, 138(6), e20163020.

Cohen, S., Klein, D. N., \& O'Leary, K. D. (2007). The role of separation/divorce in relapse into and recovery from major depression. Journal of Social and Personal Relationships, 24(6), 855-873.

Emery, R. E. (2011). Renegotiating family relationships: Divorce, child custody, and mediation: Guilford Press.

Fridman-Teutsch, A., \& Attar-Schwartz, S. (2018). Commitment to school and learning among youth in residential care: The role of mother and father support and parents' divorce. American Journal of Orthopsychiatry.

Frieman, B. B. (1994). children of divorced parents: action steps for the counselor to involve fathers. Elementary School Guidance \& Counseling, 28(3), 197-205.

Friesen, M. D., Woodward, L. J., Horwood, L. J., \& Fergusson, D. M. (2013). Quality of parentchild relations in adolescence and later adult parenting outcomes. Social Development, 22(3), 539-554.

Gardner, R. A. (1985). The boys and girls book about divorce: Bantam Books.

Golish, T. D. (2003). Stepfamily Communication Strengths. Human Communication Research, 29(1), 41-80. doi:10.1111/j.1468-2958.2003.tb00831.x 
Golombok, S. (2004). Solo mothers: quality of parenting and child development. International Congress Series, 1266, 256-263. doi:https://doi.org/10.1016/j.ics.2004.01.095

Grour, M. W., Thomas, S. P., \& Shoffner, D. (1992). Adolescent stress and coping: A longitudinal study. Research in Nursing \& Health, 15(3), 209-217. doi:10.1002/nur.4770150307

Hetherington, E. M. (1999). Should we stay together for the sake of the children. Coping with divorce, single parenting, and remarriage: A risk and resiliency perspective, 93-116.

Hetherington, E. M., Bridges, M., \& Insabella, G. M. (1998). What matters? What does not? Five perspectives on the association between marital transitions and children's adjustment. American psychologist, 53(2), 167.

Hetherington, E. M., \& Stanley-Hagan, M. M. (1995). Parenting in divorced and remarried families Handbook of parenting, Vol. 3: Status and social conditions of parenting. (pp. 233254). Hillsdale, NJ, US: Lawrence Erlbaum Associates, Inc.

Hoyt, L. A., Cowen, E. L., Pedro-Carroll, J. L., \& Alpert-Gillis, L. J. (1990). Anxiety and depression in young children of divorce. Journal of Clinical Child Psychology, 19(1), 26-32.

Kelly, J. B. (2000). Children's Adjustment in Conflicted Marriage and Divorce: A Decade Review of Research. Journal of the American Academy of Child \& Adolescent Psychiatry, 39(8), 963-973. doi:https://doi.org/10.1097/00004583-200008000-00007

Kelly, J. B., \& Wallerstein, J. S. (1977). Brief interventions with children in divorcing families. American Journal of Orthopsychiatry, 47(1), 23.

Kramer, P. A., \& Smith, G. G. (1998). Easing the pain of divorce through children's literature. Early Childhood Education Journal, 26(2), 89-94.

LeGrand, J. C. (1990). The relationship between selected biographical characteristics and anxiety and depression of participants in a divorce workshop. Texas University.

Liu, X., Kurita, H., Guo, C., Miyake, Y., Ze, J., \& Cao, H. (1999). Prevalence and Risk Factors of Behavioral and Emotional Problems Among Chinese Children Aged 6 Through 11 Years. Journal of the American Academy of Child \& Adolescent Psychiatry, 38(6), 708-715. doi:https://doi.org/10.1097/00004583-199906000-00018

Marquardt, E. (2011). Between two worlds: the inner lives of children of divorce; word and world: New York, NY: Three Rivers Press.

Mota, C. P., \& Matos, P. M. (2009). Apego, conflito e auto-estima em adolescentes de famílias intactas e divorciadas. Psicologia: Reflexão e Crítica, 22, 344-352.

Noller, P., Feeney, J. A., Sheehan, G., Darlington, Y., \& Rogers, C. (2008). Conflict in divorcing and continuously married families: A study of marital, parent-child and sibling relationships. Journal of Divorce \& Remarriage, 49(1-2), 1-24.

Ottaway, A. (2010). The impact of parental divorce on the intimate relationships of adult offspring: a review of the literature. Graduate journal of counseling psychology, 2(1), 5.

Pirak, A., Negarandeh, R., \& Khakbazan, Z. (2019). Post-Divorce Regret among Iranian Women: A Qualitative Study. International journal of community based nursing and midwifery, 7(1), 75-86.

Rescorla, L., Achenbach, T., Ivanova, M. Y., Dumenci, L., Almqvist, F., Bilenberg, N., . . . Verhulst, F. (2007). Behavioral and Emotional Problems Reported by Parents of Children 
Ages 6 to 16 in 31 Societies. Journal of Emotional and Behavioral Disorders, 15(3), 130-142. doi:10.1177/10634266070150030101

Richardson, S., \& McCabe, M. P. (2001). Parental divorce during adolescence and adjustment in early adulthood. Adolescence, 36(143), 467-489.

Rodgers, K. B., \& Rose, H. A. (2002). Risk and Resiliency Factors Among Adolescents Who Experience Marital Transitions. Journal of Marriage and Family, 64(4), 1024-1037. doi:10.1111/j.1741-3737.2002.01024.x

Samuels, V. J., Stockdale, D. F., \& Crase, S. J. (1994). Adolescent mothers' adjustment to parenting. Journal of Adolescence, 17(5), 427-443.

Steinberg, L., \& Silverberg, S. B. (1987). Influences on marital satisfaction during the middle stages of the family life cycle. Journal of Marriage and the Family, 49(4), 751-760.

Størksen, I., Røysamb, E., Holmen, T. L., \& Tambs, K. (2006). Adolescent adjustment and wellbeing: Effects of parental divorce and distress. Scandinavian Journal of Psychology, 47(1), 75-84. doi:10.1111/j.1467-9450.2006.00494.x

Szwedo, D. E., Hessel, E. T., \& Allen, J. P. (2017). Supportive romantic relationships as predictors of resilience against early adolescent maternal negativity. Journal of youth and adolescence, 46(2), 454-465.

Teachman, J. D., Paasch, K., \& Carver, K. (1996). Social Capital and Dropping Out of School Early. Journal of Marriage and Family, 58(3), 773-783. doi:10.2307/353735

Teyber, E. (2001). Helping children cope with divorce: Jossey-Bass San Francisco, CA.

Walker, J. (2003). Radiating Messages: An International Perspective. Family Relations, 52(4), 406-417. doi:10.1111/j.1741-3729.2003.00406.x

Weyer, M., \& Sandler, I. N. (1998). Stress and coping as predictors of children's divorce-related ruminations. Journal of Clinical Child Psychology, 27(1), 78-86. doi:10.1207/s15374424jccp2701_9

Wolchik, S. A., Tein, J.-Y., Sandler, I. N., \& Doyle, K. W. (2002). Fear of Abandonment as a Mediator of the Relations Between Divorce Stressors and Mother-Child Relationship Quality and Children's Adjustment Problems. Journal of Abnormal Child Psychology, 30(4), 401-418. doi:10.1023/a:1015722109114

Younesi, F., Moein, L., \& Shamshirinia, T. (2010). A Comparison of the Mental Health, SelfEsteem and Responsibility of Guidance School Girl Students from Divorced and Normal Families a Case Study of Firuzabad City. Sociology of Women (Journal of Woman and Society), 1(2), 79-95. 